\title{
Morphological Changes in The Collagen Matrix During the Subcutaneous Implantation of Fibrous Polymer Frame
}

\author{
Andrii Pantus ${ }^{1}$, Mykola Rozhko ${ }^{2}$, Ruslan Kozovyi ${ }^{{ }^{*}}$, Mykola Bahrii ${ }^{3}$, Nataliia Kovalchuk ${ }^{4}$ and \\ Iryna Yarmoschuk ${ }^{2}$ \\ ${ }^{1}$ Department of Surgical Dentistry, SHEI Ivano-Frankivsk National Medical university, Ukraine \\ ${ }^{2}$ Department of Dentistry of PE, SHEI Ivano-Frankivsk National Medical university, Ukraine \\ ${ }^{3}$ Department of Pathomorphology and Forensic Medicine, SHEI Ivano-Frankivsk National Medical university, Ukraine \\ ${ }^{4}$ Department of Clinical Pharmacology and Pharmacotherapy, SHEI Ivano-Frankivsk National Medical university, Ukraine \\ ${ }^{5}$ Department of Medical Biology and Medical Genetics, SHEI Ivano-Frankivsk National Medical university, Ukraine \\ *Corresponding author: Ruslan Kozovyi, Department of Medical Biology and Medical Genetics, SHEI Ivano-Frankivsk National \\ Medical university, Ukraine
}

\section{ARTICLE INFO}

Received: 幽 February 03, 2020

Published: 幽 February 18, 2020

Citation: Andrii P, Mykola R, Ruslan K, Mykola B, Nataliia K, et al., Morphological Changes in The Collagen Matrix During the Subcutaneous Implantation of Fibrous Polymer Frame. Biomed J Sci \& Tech Res 25(4)-2020. BJSTR. MS.ID.004236.

Keywords: Biopolymer; Bioimplant; Collagen Fibers; Cell Isolation; Cell Substrates

\section{ABSTRACT}

Background: The major challenge in tissue engineering is to optimize cell isolation, multiplication and differentiation, as well as to construct the matrices or delivery systems thereby promoting the maintenance and coordination of three-dimensional tissue regeneration. One of the important criteria that should be considered when constructing the matrix is its ability to form an optimal scaffold for the transplantation of the cell substrates.

Aim of the Study: To experimentally assess the nature of the development of the collagen scaffold during all the periods of subcutaneous implantation of the biopolymer fibrous matrix.

Materials and Methods: The study included 20 laboratory animals (rabbits) divided into 2 groups: 10 animals of Group I underwent surgery involving the creation of a subcutaneous pocket and suturing; 10 animals of Group II underwent subcutaneous implantation of the biopolymer matrix into the back area between the shoulder blades. Nine segments were used for the study, namely 1 centrally located segment, 4 segments of the paracentral zone, 4 segments of the peripheral zone. Statistical analysis of the results was conducted using software programs Microsoft Excel and Statistica 5.5 (Multiple Regression) by means of the methods of variation statistics, correlation.

Results: The results obtained indicated the absence of both acute and chronic reactive inflammatory infiltration, as well as both acute and chronic foreign-body response to the implant at the implantation site.

Conclusions: The fibrous matrix constructed by us creates a kind of the bridge for tissue ingrowth and the formation of a three-dimensional collagen matrix.

\section{Background}

Biopolymers are currently attracting increased attention in medicine and bioengineering. In tissue engineering, the materials for creating bioimplants must meet the following requirements: they must provide tissue engineered and microengineered constructs with the characteristics of living tissues, namely the ability to self-repair, as well as to change the structure and properties in response to the environmental factors [1]. The major challenge in tissue engineering is to optimize cell isolation, multiplication 
and differentiation, as well as to construct the matrices or delivery systems thereby promoting the maintenance and coordination of three-dimensional tissue regeneration [2,3]. One of the important criteria that should be considered when constructing the matrix is its ability to form an optimal scaffold in combination with optimal hemodynamics inside the scaffold to transplant the cell substrates $[4,5]$. Therefore, the aim of our study was to experimentally assess the nature of the development of collagen fibers during all the periods of subcutaneous implantation of the biopolymer fibrous matrix.

\section{Materials and Methods}

For the study, the fibrous matrix made of $100 \%$ Pure Polylactide (PLA) granules developed by us was used. The matrix was created by the method of phase separation. The average thickness of the fibrous matrix was $30 \mathrm{~mm}$. Fiber diameter ranged from $0.7 \mu \mathrm{m}$ to 10 $\mu \mathrm{m}$. The aforementioned matrices were submitted to sterilization by gamma radiation. The scaffolds, hermetically sealed in a sterile double package, were uniformly exposed to electron beam radiation with an energy of 4 mega-electron-volt (MeV) and a pulse duration of 4.5 microseconds (mcs). Each Medicom package, standardized according to EN 868-5, ISO 11140-1, ISO 11607-1, contained the polymer $0.6 \mathrm{~mm}$ in thickness. During radiation, the number of pulses changed from 4 to 70 . Sterilization was carried out according to the following parameters: accelerator frequency of $250 \mathrm{~Hz}$, maximum electron energy of $5 \mathrm{MeV}$, maximum beam power of 5 $\mathrm{kW}$, pulse duration of $4.5 \mathrm{mcs}$, pulse current of $1.5 \mathrm{~A}$, deceleration radiation power at a distance of one meter from a target substance of $104 \mathrm{R} / \mathrm{sec}$. Radiation dose was $50 \mathrm{kGy}$ based on the volume and density of the material. According to the international standards, the maximum acceptable dose is $50 \mathrm{kGy}$ at a maximum energy of $5 \mathrm{MeV}$. Treatment with electron beams with energy less than 10 $\mathrm{MeV}$ did not cause nuclear transmutations, i.e., it did not result in the formation of radioactive isotopes and did not create a residual object background radiation. After sterilization, the biopolymer matrices were subcutaneously implanted in laboratory animals.

The study included 20 laboratory animals (rabbits) divided into 2 groups: 10 animals of Group I underwent surgery involving the creation of a subcutaneous pocket and suturing; 10 animals of Group II underwent subcutaneous implantation of the biopolymer matrix into the back area between the shoulder blades. The material samples were collected on the 1st, $2 \mathrm{nd}$, 3rd months, namely the matrix alongside with the surrounding tissues was surgically removed from the animal body. All the animal manipulations were carried out in accordance with the European Convention for the Protection of Vertebrate Animals Used for Experimental and other Scientific Purposes [6]. To carry out histological examination, the matrix with the surrounding tissues was dissected in mutually perpendicular directions into 25 segments. Nine segments were used for the study, namely 1 centrally located segment, 4 segments of the paracentral zone, 4 segments of the peripheral zone. These samples were fixed in 10\% neutral formalin (Ph-7.0) for 24 hours. Then, all of the pieces of the organs studied were dehydrated in graded alcohols, defatted in chloroform, then, placed in a mixture of chloroform-paraffin (1:1), paraffin wax (at a temperature of $37^{\circ} \mathrm{C}$ ). After paraffin processing, specimens were embedded in paraffin wax. Then, 4-6- $\mu$ m-thick paraffin sections were prepared using a sliding microtome. Preparations were stained with hematoxylin and eosin [7].

Histological preparations were examined by the light-optical Leica DME microscope with different magnifications of the eyepiece and objective lens. The morphometric indicators were determined using a system for obtaining microscopic images of histological specimens (the Leica DME microscope and the Nikon P5100 digital camera) and an image processing and analysis program for Microsoft Windows Image Tool 2.0 at the Department of Pathomorphology and Forensic Medicine of the Ivano-Frankivsk National Medical University. Statistical analysis of the results was conducted using software programs Microsoft Excel and Statistica 5.5 (Multiple Regression) by means of the methods of variation statistics, correlation.

\section{Results}

Pathomorphological study of implant peripheral zones on the $1^{\text {st }}, 2^{\text {nd }}$ and $3^{\text {rd }}$ months demonstrated the development of connective tissue in the inter-fiber spaces of the implanted structure. The analysis of collagen fiber structure showed a change in the thickness of the connective tissue capsule, as well as density and location of the fibers themselves. One month after subcutaneous implantation, connective tissue of the peripheral zone contained mainly elongated fibers arranged loosely and the ground substance found in the spaces between these fibers. Fibrocytes, fibroblasts, macrophages, blood vessels were visualized in the ground substance. In the areas being in close contact with a dense fibrous layer of a polymer implant, there were seen circularly arranged connective tissue fibers with a thickness of 56.18+0.638 $\mu \mathrm{m}$ (Table 1).

Table 1: Indicators of collagen fiber thickness during all the subcutaneous implantation periods.

\begin{tabular}{|c|c|c|c|}
\hline Implantation period & Implant peripheral zone $(\boldsymbol{\mu m})$ & Implant paracentral zone $(\boldsymbol{\mu m})$ & Implant central zone $(\boldsymbol{\mu m})$ \\
\hline 1 month & $56.18+0.638$ & $20.55+0.897$ & $78.24+1.871$ \\
\hline 2 months & $83.72+1.966$ & $106.72+1.067$ & $73.49+1.567$ \\
\hline 3 months & $156.28+1.654$ & $80.24+1.174$ & 28 \\
\hline
\end{tabular}

The analysis of the indicators of implant peripheral zones 2 months after subcutaneous implantation differed from the first observation period in denser encasement of implant fiber bundles by connective tissue. Circular arrangement of collagen fibers around fiber bundles of the polymer matrix with the increase in the thickness of the connective tissue capsule to $83.72+1.966 \mu \mathrm{m}$ (Table 
1) was found as well. In contrast to the previous observation period, in the peripheral zones, between collagen fibers, spindle-shaped fibrocytes with elongated nuclei and homogeneous chromatin were found. Two months after subcutaneous implantation, single foreign body giant cells were visualized in the peripheral zones indicating hydrolysis of the material. Enlarged cells contained a significant number of diffusely arranged nuclei; their cytoplasm was light, eosinophilic, non-vacuolated. No co-existent macrophage and lymphocyte infiltration was found. Pathomorphological study of implant peripheral zones 3 months after subcutaneous implantation demonstrated the development of connective tissue, as well as adipose tissue in the inter-fiber spaces of the implant. These tissues were found to be interconnected and co-exist.

Connective tissue contained mainly densely arranged connective tissue fibers being loosely arranged in certain areas. In the areas of their loose arrangement, tortuous fibers were observed. In case of their dense arrangement, the contours of fibers were difficult to find due to their fusion with each other. In loose arrangement, several fibroblasts, macrophages, single hemosiderophages, lymphocytes (the surface area of tissue per one cell was 534.90+1.879 $\mu \mathrm{m} 2$ ) and erythrocytes were found. Within adipose tissue, there were mature adipocytes being round to polygonal in shape with small single nuclei localized below the plasma membrane at one of the margins. The blood vessels of the same caliber were visualized in adipose tissue. In contrast to the 2-month period, the increase in the thickness of the connective tissue capsule around fiber bundles of the implant to $156.28+1.654 \mu \mathrm{m}$ alongside with similar to the previous observation periods circular arrangement of connective tissue fibers containing different numbers of fibrocytes were observed (Table 1).

Pathomorphological study of implant paracentral zones 1 month after subcutaneous implantation demonstrated dense unformed connective tissue with slightly loose arrangement of connective tissue fibers. More compact circular arrangement of connective tissue fibers forming the connective tissue capsule with a thickness of $42.55+0.897 \mu \mathrm{m}$ being thinner as compared to the peripheral zone of the 1-month period was observed in some areas around fiber bundles of the polymer implant (Table 1).

In some areas, at the boundary with polymer fibers, groups of leucocytes were observed. Around PLA fibers, especially those arranged more densely, in connective tissue being in direct contact with the implant, there were detected foci of angiomatosis. In contrast to the previous observation period, pathomorphological study of implant paracentral zones 2 months after subcutaneous implantation demonstrated encasement of implant fibers by connective tissue, as well as adipose tissue. The inter-fiber spaces of the polymer matrix were filled with adipose tissue containing mature adipocytes being round to polygonal in shape. Within adipose tissue, the blood vessels of different caliber were visualized. Connective tissue filling the inter-fiber spaces of the scaffold alongside with adipose one, contained mainly connective tissue fibers and a low number of fibrocytes. Along fiber bundles of the implant, there were visualized the foci of fibroblast proliferation with round homogeneous nuclei between which there was observed a low number and, in some areas, a moderate number of neutrophil leukocytes with the segmented nuclei. In contrast to the 1-month period, single bizarre giant cells with light eosinophilic cytoplasm and multiple nuclei localized below the plasma membrane and in the central part of the cell were observed. Between individual fiber bundles of the implant in connective tissue, the foci of moderate macrophage and lymphocyte infiltration indicating hydrolysis of the material were visualized. The thickness of the connective tissue capsule was $78.24+1.871 \mu \mathrm{m}$ higher as compared to the previous observation period; however, it was slightly lower as compared to the peripheral zone 2 months after implantation (Table 1).

Similar to the previous observation period, histomorphological study of implant paracentral zones 3 months after subcutaneous implantation demonstrated filling of the inter-fiber spaces of the implant with both connective and adipose tissues. Adipose tissue contained mature adipocytes; thin-walled blood vessels of different caliber filled with erythrocytes. Dense unformed connective tissue of the inter-fiber spaces of the polymer matrix was similar by its structure to the peripheral zones 1 month after implantation. In some areas, there were observed bundles of collagen fibers; fibers were elongated, occasionally wavy, tortuous. Between connective tissue fibers, fibrocytes with elongated oval nuclei, a low number of fibroblasts and macrophages were found. In other areas, tortuous, more loosely arranged connective tissue fibers were observed; no fiber bundles were observed. In contrast to implant peripheral zones 3 months after implantation, there was observed a decrease in the thickness of the collagen capsule to $106.72+1.067 \mu \mathrm{m}$; however, this indicator was higher as compared to that 2 months after implantation (Table 1). Similar to all the periods and implant zones, within the capsule, connective tissue fibers circularly arranged around fiber bundles of the polymer were found; compact arrangement of collagen fibers was seen. Between collagen fibers, fibrocytes as well as fibroblasts with more rounded nuclei as compared to fibrocytes were detected. Single multinucleated giant cells without any reactive lymphocyte, macrophage, epithelioid cell reactions were occasionally seen.

According to pathomorphological study of implant central zones 1 month after subcutaneous implantation, the inter-fiber spaces of the implant were filled with connective tissue being identical to that in the paracentral and peripheral zones. In connective tissue, collagen fibers predominated. In some areas, fibers were densely arranged forming a fiber mass; in other areas, the ground substance was found between fibers. In the first case, the number of fibrocytes and fibroblast was lower; in the second case, it was higher. An opposite correlation between fiber arrangement and the number of macrophages and lymphocytes was noted. In case of loose arrangement, macrophage foci and a small number of lymphocytes were visualized in the ground substance, mainly in the perivascular 
zone. PLA fibers of the implant were encased by the connective tissue capsule with an average thickness of $20.41+0.882 \mu \mathrm{m}$ being thinner as compared to the peripheral and paracentral zones of the same period (Table 1). In connective tissue, there were areas with slightly pronounced segmental leukocyte infiltration around polymer fibers, that was not observed at the periphery.

Pathomorphological study of implant central zones 2 months after subcutaneous implantation demonstrated the development of both connective and adipose tissues in the inter-fiber spaces of the polymer scaffold in both the paracentral zone of this period and the peripheral and paracentral zones of the 3-month period. Fiber bundles were encased mainly by thin connective tissue capsules with an average thickness of $73.49+1.567 \mu \mathrm{m}$ being thinner as compared to the paracentral zone of the same period but thicker than those 1 month after implantation (Table 1). In these fibers, fibrocytes and fibroblasts arranged circularly around polymer fibers were seen. Foreign body giant cells with multiple nuclei were visualized around individual bundles of polymer fibers; epithelioid cell reaction was absent. Macrophages and a low number of neutrophil leukocytes were observed within the capsules around the fibrous polymer matrix. Connective tissue filling the inter-fiber spaces of the polymer matrix alongside with adipose tissue contained loosely arranged connective tissue fibers. Between fibers, there were observed fibrocytes with elongated oval nuclei, several fibroblasts with round to oval nuclei, macrophages, lymphocytes, foci of neutrophil leucocytes (the surface area of cellular infiltration per one cell was $528.42+3.105 \mu \mathrm{m} 2$ ). Adipose tissue containing mature adipocytes and connective tissue were found to be interconnected and co-exist.

According to pathomorphological study of implant central zones 3 months after subcutaneous implantation, the inter-fiber spaces of the implant were filled with connective tissue and, to a lesser extent, with adipose one. Connective tissue contained connective tissue fibers located some distance apart from each other and separated by the ground substance of connective tissue. The ground substance contained limited cell number (fibrocytes, fibroblasts, macrophages), small focal clusters of macrophages and lymphocytes (the surface area of connective tissue per one cell was $446.31+1.968 \mu \mathrm{m} 2$ ). In some areas, within connective and adipose tissues of the inter-fiber spaces of the implant, focal cellular infiltration represented mainly by lymphocytes and, to a lesser extent, by macrophages was observed. In some areas, perivascular infiltration was seen. In one case, there was observed focal lymphocyte clustering in the central part of which slightly enlarged macrophages with a moderate amount of light cytoplasm similar to epithelioid cells were seen. Similar to other zones studied, implant fibers were encased by the connective tissue capsules with an average thickness of $80.24+1.174 \mu \mathrm{m}$ being thinner as compared to the peripheral and paracentral zones of the same period but thicker as compared to the central zones of two previous observation periods (Table 1 ).
Similar to all the zones during all the observation periods, within the capsules, connective tissue fibers were found; between these fibers, there were seen fibrocytes and a low number of fibroblasts. Within the capsule of certain fiber bundles of the implant, focal macrophage and lymphocyte infiltration, that was found to be slightly extended beyond the capsule, with individual neutrophil leukocytes was seen. In some areas, the blood vessels were found to be close to the capsule. When studying the inside of the capsule being in direct contact with polymer fibers of the implant, several bizarre multinucleated giant cells of different sizes with abundant eosinophilic cytoplasm and multiple nuclei arranged diffusely were observed. In animals of the control group, there were no signs of circular arrangement of fibers with a clear systemic geometric orientation. There was no significant difference in collagen fiber thickness between two groups. There was found the difference in leukocyte infiltration that was absent in animals of the control group. There was no tissue macrophage response; foreign body giant cells were absent.

\section{Discussion}

Based on the studies conducted, collagen fiber was found to grow and form within the entire fibrous polymer matrix in three perpendicular directions. This fact confirmed frame function of a polymer network synthesized by us, i.e., bundle of polymer fibers creates a kind of scaffold for tissue formation. The analysis of the indicators of the connective tissue capsule demonstrated a clear dynamic depending on implantation period and implant zone. Thus, a decrease in the indicators of fiber thickness from the peripheral part to the central one within the single observation period indicated a clearly fixed type of implant regeneration in all directions, i.e., within the time interval, fibers of the peripheral zones began to organize faster than those in the paracentral and central zones. When comparing the observation periods within a certain zone, there was observed a reverse trend toward the increase from the first to the third periods, that indicated the continuation of biosynthetic processes within a certain implant sector, as indicated by the presence of fibroblasts in almost all zones. During all the observation periods and in all the zones, the same type of circular arrangement of fibers was observed. Two months after subcutaneous implantation, there were found the signs of material hydrolysis manifested by the presence of single foreign body giant cells and macrophages in both the peripheral zones of the implant and its central zone, that was not observed in animals of the control group.

\section{Conclusions}

a) The absence of a significant number of neutrophil leucocytes, an increased number of macrophages and lymphocytes indicated the absence of both acute and chronic reactive inflammatory infiltration, as well as both acute and chronic foreign-body response to the implant at the implantation site. 
b) The fibrous matrix constructed by us, due to its hygroscopicity and porosity, creates a kind of the bridge for tissue ingrowth and the formation of a three-dimensional collagen matrix.

\section{References}

1. Olesova VN, Dovbnev VA, Evstratov OV, Zveryaev AG, Zuev MD, Lesnyak AV (2013) Preimuschestva vremennyih nesyemnyih frezerovannyih i polimerizovannyih plastmassovyih protezov na implantatah Klinichiskie issledovaniya 1: 25-26.

2. Andryushechkina TN, Berchenko GN, Gioeva YUA, Zoryan EV, Atrushkevich VG (2015) Vliyanie kompleksnyih antigomotoksicheskih preparatov na tkani parodonta $\mathrm{v}$ aktivnom periode ortodonticheskogo lecheniya: eksperimentalno-morfologicheskoe i klinicheskoe issledovanie. Klinicheskaya stomatologiya 4: 42-49.

ISSN: 2574-1241

DOI: $10.26717 /$ BJSTR.2020.25.004236

Andrii Pantus. Biomed J Sci \& Tech Res

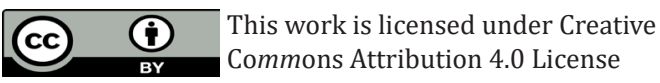

Submission Link: https://biomedres.us/submit-manuscript.php
3. Balin VN, Balin DV, Iordanishvili AK, Muzyikin MI (2015) Osteostimuliruyuschee deystvie ksenogennogo kostnogo materiala na reparativnyiy osteogenez (eksperimentalno-morfologicheskoe issledovanie). Stomatologiya 94(2): 5-9.

4. Hayashi CH, Gudino CV, Gibson FC, Genco CA (2010) Review: pathogeninduced inflammation at sites distant from oral infection: bacterial persistence and induction of cells pecific innate immune inflammatory pathways. Mol Oral Microbiol 5(25): 305-316.

5. Deev RV, Isaev AA, Kochish AYU, Tihilov RM (2016) Kletochnyie tehnologii $\mathrm{v}$ travmatologii i ortopedii: puti razvitiya. Kletochnaya transplantologiya i tkanevaya injeneriya 3(6): 22-33.

6. Poriadok provedennia naukovymy ustanovamy doslidiv, eksperymentiv na tvarynakh. Ofitsiinyi visnyk Ukrainy. Ofits Vyd 24: 82.

7. Bahrii MM, Dibrova VA, Popadynets OH (2016) Hryshchuk MI Metodyky morfolohichnykh doslidzhen: Monohrafiia. Vinnytsia Nova knyha 328.

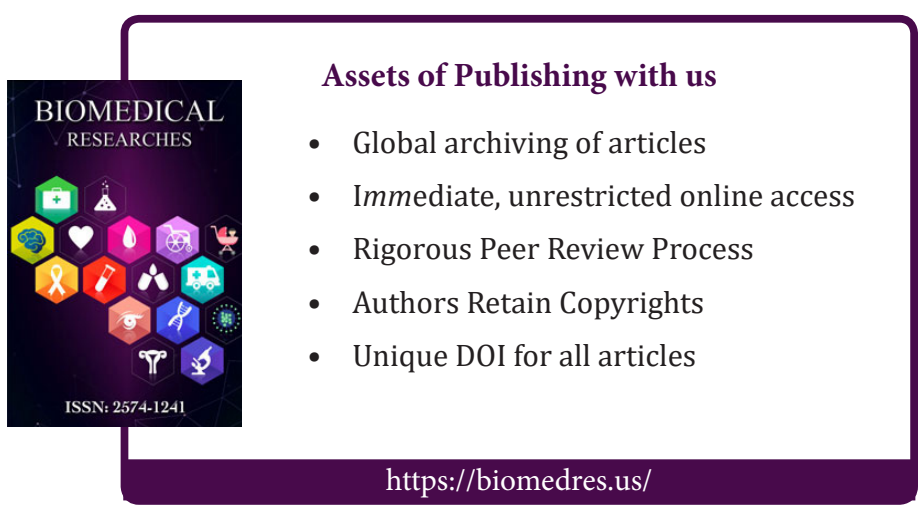

